\title{
Reducing Poverty through Optimization of Zakat on Agriculture and Profession
}

\author{
Siectio Dicko Pratama \\ BPS-Statistics of Lampung Utara Regency, Indonesia \\ Corresponding email: siectio@hotmail.com \\ Rezha Nursina Yuni \\ BPS-Statistics of Indragiri Hilir Regency, Indonesia
}

Received: June $13^{\text {th }}, 2020$ Revised: August $8^{\text {th }}, 2020$ Accepted: August $30^{\text {th }}, 2020$

\section{Abstract}

Zakat is a system in Islam that is designed to allocate the wealth from the rich to the poor and the needy. The effectivity of zakat in reducing poverty has been proven in the history of Islam. Nevertheless, nowadays, Zakat is still unable to eliminate poverty. Bad planning and organizing of zakat are the main reason for that especially the less information about the potency of zakat in each region. Indonesia is a country that is rich in Natural Resources and has many workforces. So, Indonesia may have hidden potential of agricultural and professional zakat. This study tries to calculate the potency and the impact of the zakat on reducing poverty. The effect will be examined descriptively and statistically and also will be presented by mapping all the provinces in Indonesia. The result shows that there are about 16.1 trillion rupiahs of zakat potential furthermore able to reduce the poverty rate in Indonesia for 0.75 percent. DKI Jakarta is the most affected province by zakat because its poverty rate reaches 0.22 percent. To implement this theory in real practice, the utilization of the mosque to distribute zakat funding where BAZNAS represents as the manager is suggested.

Keywords: Poverty Gap, Poverty Reduction, Zakat on Profession, Zakat on Agriculture. JEL Classification: P36, D63, D31

@ IJIEF 2020 published by Universitas Muhammadiyah Yogyakarta, Indonesia All rights reserved

DOI:

https://doi.org/10.18196/ijief.3237
Web:

https://journal.umy.ac.id/index.php/ijief/article/view/9029

Citation:

Pratama, S. D., \& Yuni, R. N. (2020). Reducing poverty through optimization of zakat on agricultural and profession. International Journal of Islamic Economics and Finance (IJIEF), 3(2), 145-174. DOI: https://doi.org/10.18196/ijief.3237 
Pratama \& Yuni | Reducing Poverty through Optimization of Zakat on Agriculture and Profession

\section{Introduction}

\subsection{Background}

Islam is a religion which gives much attention to social welfare, as it is cited in Qur'an Surah Al-Hashr verse 7,"...so that it will not be a perpetual distribution among the rich from among you". This verse shows that in Islam, the property should not only amongst the rich but also has to be welldistributed to those who need it. Hence, there is a command in Islam which obliged the Muslim to give some of their wealth to the poor, called zakat. In general, all people whose wealth exceeding their basic needs and the wealth remains intact in a year must pay zakat. Furthermore, they who receive zakat must be in eight categories mentioned in Qur'an, those are; the poor, the needy, zakat administrators, new Muslim (those whose hearts are to be reconciled), those in slavery, the debt-ridden, Muslim who strive into God and the wayfarer (Sabiq, 2013). Therefore, zakat should be able as a solution to eliminating poverty.

The main reason why zakat should be the best solution to alleviate poverty, especially extreme poverty, is that the recipients are the poor and the needy. It is different from tax. The distribution of tax does not require a certain group of people. It depends on the government.

The effectivity of zakat in eradicating poverty is not only on paper. It is proven from the history that at least in two periods of government, zakat has been successfully forming complete alleviation of poverty in two periods of time, the second Islamic caliphate of Islam Umar bin Khattab R.A (13-22 H) and Umar bin Abdul Aziz (99-101H). At that time, eligible recipients of zakat were none because of the prosperity at that period. The key to success in those periods is proper planning and worthy management (Arif, 2017). Inadequate information about how much zakat has been collected also can be a reason why the implementation of the zakat system cannot be as good as before in history (Ismail, 2013). The reason why zakat cannot give a significant impact on poverty reduction could be due to so much potential zakat which is unreached all this time.

It is commonly known that Indonesia is an agricultural country. About 12.72 percent of Gross Domestic Product is the agricultural sector. Moreover, 27.33 percent of all workers, which is the highest proportion, are from agricultural workers (BPS-Statistics of Indonesia, 2020). It is a fact that the agricultural sector has a significant impact on the majority of Indonesian. Nevertheless, the amount of zakat collected from agriculture remains unclear, although the zakat rate is higher at 5 or 10 percent. By looking at the potential, the agricultural sector should contribute more to zakat collection. 
Pratama \& Yuni | Reducing Poverty through Optimization of Zakat on Agriculture and Profession

Another hidden potential of zakat in Indonesia is zakat on profession. Research conducted by Asfarina et al. (2019) estimated that the potential of zakat on household income using Contemporary Figh Approach under realistic scenario reaches Rp34.73 trillion, while the total zakat collected by Amil Zakat National Agency (BAZNAS) was only Rp8.2 trillion in 2018. It means that there were about Rp26.53 trillion of realistic zakat potential that cannot be realized. Then, if we simply focus on developing the collection of professional zakat, we might be able to increase the zakat collection significantly. The unavailability of the zakat potential data specifically on profession at the regional level makes it difficult to develop proper management in collecting zakat.

The studies on zakat have been conducted by many researchers and practitioners such as Firdaus et al. (2012) and Asfarina et al. (2019) who studied the potential of zakat in Indonesia. Notwithstanding, the studies on the zakat potential and its connection to poverty alleviation are still scarce. Study by Shirazi et al. (2009) estimated the potential zakat collection and the resource required for eliminating poverty. Thus, studies to analyze the influence of zakat potential for the specific kinds of zakat are urgently needed. Hopefully, this research can provide a basic foundation for further studies about the other kinds of zakat potential and the effort to alleviate poverty through the zakat instrument.

\subsection{Objectives}

Faulty planning on managing zakat has been a major reason why the application of the zakat system meets failure (Arif, 2017). One of the reasons while devising improper planning is inadequate information about the characteristic of a regency, the unknown target measurement of zakat collected, and even the uncertainty about the effectivity of the zakat system itself. Accordingly, the main goal of this research is to calculate the potential of agricultural zakat, profession zakat, and the income shortfall of the poor people from the poverty line and then map them by provinces based on certain levels. Besides, the impact of zakat potential on the poverty gap will also be examined statistically to make sure whether the zakat system is effective in alleviating poverty.

The organization of this paper will be explained as follows. The background theory related to this study and previous researches will be discussed in Chapter 2. Chapter 3 will reveal the data used in this research from the source of data and ways to cover the limitation of data. Moreover, the model development and method used will also be discussed in this Chapter. Chapter 4 will discuss the findings from all of the analysis used and the 
Pratama \& Yuni | Reducing Poverty through Optimization of Zakat on Agriculture and Profession

possible practical implementation from those findings. Lastly, the conclusion of the research will be provided as well as the recommendations for further researches, practitioners, and policymakers in Chapter 5.

\section{Literature Review}

\subsection{The Definition of Poverty}

Poverty is strongly related to the lack of well-being means that poor people are those who cannot live in prosperity. It is defined as an inability of someone to fulfill basic needs such as food, clothing, health, housing, and education. These minimum basic needs then interpreted into a financial measurement in the form of money which is known as a poverty line. They whose income below the poverty line are categorized as the poor ones (Haughton \& Khandker, 2009). Nevertheless, Islam defines poverty in two viewpoints: quantitative and qualitative explanation. In a qualitative view, a person can be considered as a poor when he is informed by at least three well-informed and trusted persons in the same clan. When come to the quantitative interpretation, someone is mentioned as poor when he has assets less than four dinars (Peerzade, 1997).

The poverty line becomes a significant aspect of measuring poverty. It is counted by summing the food poverty line and the non-food poverty line. The food poverty line is the value of the expenditure to fulfill the basic needs of food which is equal to 2100 kilocalories per capita per day. Besides, the non-food poverty line is the minimum need for housing, clothing, education, health, and other non-food basic needs. All the needs both food and nonfood are groups by packs of commodity, 52 commodities for food and 51 commodities for non-food in urban and 47 commodities in rural.

Poverty also can be analyzed from the perspective of gap and severity. The poverty gap index shows the average income of people below the poverty line. It is also able to be named as the proportion of the poverty line. If all the poverty gaps of each individual are summed up, we will obtain the minimum cost to reduce the poverty with the assumption of perfect distribution. Meanwhile, the poverty severity index is the square of the poverty gap index. It is used to describe the inequality of income among the poor (Haughton \& Khandker, 2009). 
Pratama \& Yuni | Reducing Poverty through Optimization of Zakat on Agriculture and Profession

\subsection{The Zakat System in Islam}

In literary terms, the meaning of zakat is to grow, to develop, and to bless. It is mentioned in the Qur'an Surah At-Taubah verse 103," Take from their wealth a charity by which you purify them and cause them to increase". It is the reason for zakat to be a purifier of wealth, an improvement of goodness, and a wish to get the blessing (Sabiq, 2013). Zakat is conceptually defined as particular taking from determined wealth by special conditions and for the specific recipients (Kausar et al. 2016).

Zakat is charged neither to everyone nor to every wealth. There are specific conditions where Muslims are obliged to pay zakat. If the wealth of Muslims does not meet the conditions, then they have no obligation to pay zakat. Zakat is supposed to be obtained to the wealth in this six requirements; 1 ) Islam, it is required only for Muslims, 2) Zakat payers must be in healthy mind and soul, 3) the wealth is fully under his ownership, 4) the riches are developed or have the potency to grow, 5) reach the nisab or minimum amount of wealth that must be paid for zakat, and 6) has been under the settlement for at least a year (Huda et al. 2008).

Zakat also has various kinds. In general, zakat consisted of Zakat Al-Fitr and Zakat Al-Mal (Aisyah, 2014). Zakat Al-Fitr is given during Ramadhan for every adult Muslim whose extra food for their own. They have to pay zakat 2.5 kilograms of staple food which is normally consumed in a region, intended as purification of Muslims who have fasted in full month with a goal that everyone in Eid Al-Fitr will break their fast and celebrate the day delightfully. On the contrary, Zakat Al-Mal is meant to purify the wealth. The people who are over wealth should donate some of their wealth to those who need it. There are eight types of zakat on wealth: Zakat on Income, Zakat on Business, Zakat on Savings, Zakat on Gold and Silver, Zakat on Shares, Zakat on Livestock and Zakat on Crops. Yet, this research defines the coverage into two types: zakat on incomes (zakat on profession) and zakat on agricultural products (the sum of zakat on livestock and crops).

Zakat on agricultural product is zakat which is charged for plants that have any economic value such as grains, tubers, vegetables, fruits, and all the plants which are meant to be invested or developed. Agricultural zakat does not need any requirement to own in a year because it is paid at harvest. People whose obligatory to pay zakat on agriculture are they whose yields more than $750 \mathrm{~kg}$ for basic food (Ministry of Religion, 2011). Different from others, the value of agriculture is not 2.5 percent but depended on the irrigation system. If the irrigation system is from rain or river or anything free, then the value is 10 percent of yields. But if the irrigation system requires the farmers to purchase water, then the value is 5 percent only. 
Pratama \& Yuni | Reducing Poverty through Optimization of Zakat on Agriculture and Profession

Meanwhile, if the irrigation system is the combination of those two ways, the amount of zakat is about 7.5 percent (Rahman et al. 2014).

Another type of zakat is zakat on profession. Similar to agricultural zakat, zakat on profession is also presented when earning income. This kind of zakat is required to be charged from people with these requirements; Islam, independence, full ownership, getting income in halal ways, exceeding the limit of nisab, and fulfilling haul (Ministry of Religion, 2011). Zakat on profession is charged for every kind of income whether it is routine or not. It includes salaries, wages, honorariums, or services that have been more than nisab. The nisab is one by twelve of 85 grams of gold per month. If in a month the income meets the nisab, then the calculation of zakat on profession is 2.5 percent of income (Center of Strategic Studies -Amil Zakat National Agency, 2019).

\subsection{Previous Studies}

One of the popular researches in Indonesia when it comes to the estimation of zakat potential is research conducted by Firdaus et al. (2012). The research estimates the total amount of zakat in Indonesia is about 217 trillion rupiahs. The method of the research is quite comprehensive because it has covered the household units, the companies, BUMN, and even the government. Asfarina et al. (2019) modified the estimation by conducting research to estimate the potential of zakat using better proxies and calculation methods as well as various fiqh approaches. The result of the study stated that the potential zakat in Indonesia is only about 69.57 trillion rupiahs under the classical figh approach. But, when it is under the contemporary figh approach, the result is 216.54 trillion rupiahs.

Another research conducted by Shirazi et al. (2009) compared the estimation of zakat potential and the required resource to eradicate poverty. The study covered 38 OIC-member countries. The resource shortfall was predicted by using the poverty gap index. The multiplication between the poverty gap index, poverty line, and the total population was defined as the total amount required to bring all the poor people up to the poverty line. Meanwhile, the zakat potential is estimated by using National Income Approach. The result revealed that the estimated potential of zakat had covered all the resource shortfall in half of the sample countries. Not only that, but all those countries also produce surplus funds which are adequate to cover other countries which experienced the deficit resource. 
Pratama \& Yuni | Reducing Poverty through Optimization of Zakat on Agriculture and Profession

Some kinds of zakat also have impacts on poverty. Mujiatun (2018) with his research in Medan City concluded that zakat on profession, even it had not been optimal yet, was capable of reducing poverty. The research in Tegalsari District about the management of zakat in coping poverty conducted by Syafa et al. (2020) concluded that proper utilization of profession zakat will eradicate poverty at the regional and national levels. The even distribution of agricultural zakat potential to the poor people was proved to decrease the poverty level according to Rarasati \& Dewanti (2018). It is not only the poverty level, but the well-distribution of agricultural zakat was also capable to lessen the depth and the severity of poverty. Surely, both zakat on profession and zakat on agriculture has a significant impact on eliminating poverty.

\section{Methodology}

\subsection{Data}

The most significant concern in any researches about zakat particularly at the macro level is the availability of data. The low availability of data regarding zakat at the province either national level forces this research to do some approaches. In general, we use the ratio between muzakki and Muslim workers in each province to perceive the number of people who required to pay zakat. This ratio is an approach to the nisab of zakat. Because we could not determine the data of people whose obligatory to pay zakat by their kind, so we use this approach to estimate the number of muzakki. The ratio later is used by multiplying the average income of workers and the total workers to get the estimated zakat potential in a region. The number of muzakki in every province in Indonesia is adapted from the research conducted by Ahsan et al. (2009). Meanwhile, the total of Muslim workers is the total of workers multiplied by the comparison between the Muslim and general population. This ratio will be calculated for specific kind of zakat with the formula as follows

$$
\text { a. } \quad R_{x i}=\frac{M_{i} \cdot T P_{i}}{M P_{i} \cdot T W_{x i}}
$$

Notes:

$R_{i} \quad$ : The ratio of Muzakki and Muslim Workers for Zakat $x$ in province $i$

$M_{i} \quad$ : The number of muzakki in province $i$

$T P_{i} \quad$ : Total Population in province $i$

$M P_{i}$ : Muslim Population in province $i$

$T W_{x i}$ : Total Workers of Sector $x$ in province $i$ 
Pratama \& Yuni | Reducing Poverty through Optimization of Zakat on Agriculture and Profession

Due to specific data of muzakki was 2007's condition, the workers' data was also in the same condition precisely in August 2007 which both were available on Statistics Indonesia's website. Nonetheless, the ratio between Muslims and all populations is more updated because 2007 data is unavailable. The data is from 2010's Population Census published by BPSStatistics Indonesia (Sub-directorate of Demographic Statistics, 2011). Yet, because North Kalimantan is the new province in 2012, its data taken from the publication released by BPS-Statistics of East Kalimantan (Division of Integrated Processing and Statistical Dissemination, 2012). It counts by summing up the total of Muslims in the districts whereas presently being part of North Kalimantan.

Zakat on agricultural products is required to be charged by the term the agricultural products reach the equivalent of $625 \mathrm{~kg}$ rice. The amount is about 10 percent for non-irrigated field and 5 percent for the irrigated field. If the field is the combination of irrigated and non-irrigated, then the amount of zakat is about 7.5 percent. Therefore, it comprehended that people who required to pay agricultural zakat are those whose agricultural business and products are more than $625 \mathrm{~kg}$ of rice. To approach this, the data that we used is the agricultural sector's self-employed workers. For estimating the muzakki, as we explained, the muzakki-Muslim workers' ratio is being used. The estimated amount of zakat is applied by using the average of the agricultural sector's self-employed workers for a year. This data then multiplies by the number of estimated muzakki and 0.075 which is resulted from the amount of required zakat (7.5 percent is mixed of irrigated and non-irrigated field). The formula below is literally adopted from Ahsan et al. (2009) and Rosele et al. (2014). It is then modified and adjusted by the availability of the data and the condition in Indonesia. This is the equation:

$$
Z_{a i}=I_{a i} \times 12 \times 0.075 \times\left(W_{a i} \times R_{a i}\right)
$$

Notes:

$Z_{a i}$ : The estimated amount of agricultural zakat in province $i$

$I_{a i}$ : The monthly average income of self-employed workers in the agricultural sector in province $i$

$W_{a i}$ : Total self-employed workers in the agricultural sector in province $i$

$R_{a i}$ : The ratio of muzakki and Muslim workers for agricultural zakat in province $i$

Furthermore, zakat on profession is also charged for people whose monthly income is equivalent to $625 \mathrm{~kg}$ of rice consumed daily. The term to pay this zakat is also similar to the zakat of agriculture. The zakat is paid when we get the income with the amount is higher than $625 \mathrm{~kg}$ rice. The difference is for people whose income and amount of money is not 5 nor 10 percent but 2.5 
Pratama \& Yuni | Reducing Poverty through Optimization of Zakat on Agriculture and Profession

percent. Because of that, the formula to estimate the amount of zakat on profession is almost similar to the agricultural zakat. The formula to measure the professional zakat potential is literally adopted from Asfarina et al. (2019) and Ahsan et al. (2009) as main references to build the equation with some adjustments and modifications. Hereabouts is the formula to get the zakat potential on the profession.

$$
Z_{p i}=I_{p i} \times 12 \times 0.025 \times\left(W_{p i} \times R_{p i}\right)
$$

Notes:

$Z_{p i} \quad$ : The estimated amount of zakat on profession in province $i$

$I_{p i} \quad$ : The monthly average income of all workers as employees in province $i$

$W_{p i}:$ Total workers as employees in province $i$

$R_{p i}$ : Muzakki-Muslim workers ratio for all workers as employees in province $i$

\subsection{Model Development}

The zakat potential is defined by zakat on agricultural products and zakat on profession. According to Rarasati \& Dewanti (2018), agricultural zakat was able to reduce the depth of poverty which also help to reduce the poor people. Besides, Shirazi et al. (2009) found that the potential of zakat estimated from three different opinions of zakat (including the type of zakat similar to profession zakat) was sufficient to fulfill the resource shortfall of poor people under $\$ 1.25$ a day and $\$ 2.0$ a day of the poverty line. $Z 2$ alone (potential of zakat similar to zakat on profession) had been enough to provide the income shortfall of the poor using $\$ 1.25$ a day of the poverty line. Therefore, preliminary hypothesis in this research is both the potential of agricultural and profession zakat will reduce the poverty. Following Novignon et al. (2012), the proposed model is as follows:

$$
\ln P_{m}=\alpha+\ln \beta Z_{t}+\ln \gamma Z_{p}+\varepsilon
$$

Notes:

$P_{m i} \quad:$ The poverty gap index in province $i \quad \alpha \quad$ : Constant

$Z_{t i}$ : The estimated amount of agricultural $\quad \beta \quad$ : Regression coefficient of $Z_{t i}$ zakat in province $i \quad \gamma \quad$ : Regression coefficient of $Z_{p i}$

$Z_{p i}:$ The estimated amount of zakat on $\varepsilon \quad$ : Error Term profession in province $i$ 
Pratama \& Yuni | Reducing Poverty through Optimization of Zakat on Agriculture and Profession

\subsection{Method}

The methods applied in this study are poverty gap index analysis, geospatial analysis, and multiple linear regression. The poverty gap index analysis is applied to measure the income shortfall of the poor as the poverty line determined by BPS-Statistics of Indonesia. Therefore, the poverty line will specifically depend on each province. Afterward, the calculation of both zakat potential and the income shortfall give the result that will be mapped by using geospatial analysis to ease the interpretation. In this section, we also examine the impact of zakat potential on poverty descriptively. Lastly, the advanced model will be estimated by the procedure of multiple linear regression. All the methods will be explained further in the following paragraphs.

The poverty gap index is the gap within the income of the poor from the poverty line. Furthermore, it is also the minimum cost to eliminate poverty so it will enable us to know how much money transferred to the poor until their income can be upward to the poverty line (Haughton \& Khandker, 2009). The multiplication between the poverty line, the poverty gap index, and the sum of the population in the regency will estimate how much money is needed to send all the poor upward to the poverty line. It is following the formula of resource shortfall measured by Shirazi et al. (2009). After obtaining the result of the income shortfall calculation, the estimated of zakat potential will be applied as the deduction to the shortfall. Then, the excess of the income shortfall after subdued by zakat potential will be transformed into a new poverty rate for each province in Indonesia. It obtained by proportioning the excess of the income shortfall with the total income shortfall then multiplying it with the poverty rate.

Geospatial analysis is defined as a technique to analyze data by referencing the two-dimensional minimum frame and relating it to the territory (Smith et al. 2018). We use this approach to ease the interpretation and analysis calculation of the agricultural and the profession zakat. It also counts the income shortfall of poor people. The principal thing about geospatial analysis is the classification method. Consequently, we use a popular method which frequently used in any spatial analysis named Jenks's natural breaks. This method optimizes data set into multiple classes based on the gap which is generally applied in the data distribution. Accordingly, the variance within classes will be minimum and between classes will be maximized. To achieve the condition, data in a class whose big deviation of the class average will be transferred to another class (Jiang, 2012).

The method used to examine the advanced model is multiple linear regression. This popular technique has some utilizations, those are; a) the 
Pratama \& Yuni | Reducing Poverty through Optimization of Zakat on Agriculture and Profession

value of effect from every independent variable to dependent variables are simultaneous and even partial, b) the comparison effect between applied independent variables to dependent variables, and c) the prediction of the dependent variable value. To implement this analysis, we need to have a minimum of five observations of each independent variable and fulfill all the basic assumptions of the multiple linear regression model (Asra et al. 2017; Hair et al. 2010). The assumptions requirement must be fulfilled to produce the Best Linear Unbiased Estimators (BLUEs). The estimation of parameters from that model will be valid and reliable. The assumptions are linear in parameters, no serial correlation, no perfect collinearity, zero conditional mean, homoscedasticity, and normality (Wooldridge, 2009).

\section{Result and Analysis}

\subsection{Results}

\subsubsection{The Potential of Zakat in Indonesia}

The calculation of zakat potential produces that there is 18.77 trillion rupiahs potential of zakat in Indonesia. In particular, the total of agricultural zakat potential is about 2.57 trillion rupiahs, and about 16.2 trillion rupiahs rest is the potential of zakat on profession. The total fund of zakat potential is almost triple higher than the amount of zakat collected by BAZNAS in 2017 which is about 6.2 trillion rupiahs (Center of Strategic Studies -Amil Zakat National Agency, 2019). The total amount of profession zakat interestingly is almost equivalent to the projection of zakat potential for Civil Servant in Indonesia. It predicts that the zakat potential of civil servants enables them to reach 10 trillion (Widjaja, 2018). There is only about 6 trillion difference with projected zakat. Consider that the profession zakat in this paper limited only to cover the workers with regular incomes, the estimation is wellearned. Hence, the zakat potential can be optimized with a proper rule from the government or even the right policy from authorized institutions.

Table 1 shows the amount of zakat potential by types and provinces. DKI Jakarta and Jawa Barat are provinces with the highest zakat potential. Both of them are supported by high zakat on profession that reaches about 3.150 billion and 3.116 billion rupiahs. The contribution of zakat on agriculture in the provinces is quite small. Riau and Nusa Tenggara Timur are the provinces with the most zakat potential on agriculture. This is particularly remarkable because NTT is a province where Muslims are not the majority. The high potential zakat on agriculture in NTT perhaps caused by self-employed workers in the agricultural sector is quite high with proportion around 58 
Pratama \& Yuni | Reducing Poverty through Optimization of Zakat on Agriculture and Profession

percent of the total workers. Besides, the Gross Domestic Regional Product (GRDP) from the agricultural sector also contributes approximately 27 percent of total GRDP, the highest sector of all in regencies and municipalities in NTT. Moreover, the proportion of muzakki and the Muslim population in NTT reaches 74 percent which is the highest of all provinces. The data explains why zakat potential on agriculture in NTT is high.

Table 1. The result of the measurement of Zakat Potential in Indonesia by Provinces

\begin{tabular}{lccc}
\hline \multicolumn{1}{c}{ Provinces } & $\begin{array}{c}\text { Zakat on } \\
\text { Agriculture (Million } \\
\text { Rupiahs) }\end{array}$ & $\begin{array}{c}\text { Zakat on Profession } \\
\text { (Million Rupiahs) }\end{array}$ & $\begin{array}{c}\text { Total of Zakat } \\
\text { Potential (Million } \\
\text { Rupiahs) }\end{array}$ \\
\hline Aceh & $102,853.13$ & $258,694.01$ & $361,547.14$ \\
Sumatera Utara & $151,653.93$ & $671,618.19$ & $823,272.12$ \\
Sumatera Barat & $82,094.73$ & $247,905.96$ & $330,000.69$ \\
Riau & $289,375.73$ & $647,663.28$ & $937,039.02$ \\
Jambi & $120,626.17$ & $190,146.37$ & $310,772.54$ \\
Sumatera Selatan & $126,427.67$ & $289,970.28$ & $416,397.95$ \\
Bengkulu & $18,319.02$ & $45,990.76$ & $64,309.78$ \\
Lampung & $73,107.86$ & $158,019.74$ & $231,127.60$ \\
Kep. Bangka Belitung & $60,746.17$ & $188,104.07$ & $248,850.24$ \\
Kep. Riau & $5,519.18$ & $619,570.49$ & $625,089.66$ \\
DKI Jakarta & $8,877.41$ & $3,150,672.74$ & $3,159,550.16$ \\
Jawa Barat & $123,248.28$ & $3,115,897.70$ & $3,239,145.97$ \\
Jawa Tengah & $84,801.46$ & $609,502.79$ & $694,304.25$ \\
Di Yogyakarta & $11,698.47$ & $193,685.54$ & $205,384.02$ \\
Jawa Timur & $160,043.93$ & $875,715.83$ & $1,035,759.76$ \\
Banten & $53,243.83$ & $1,488,293.47$ & $1,541,537.30$ \\
Bali & $33,386.40$ & $403,944.20$ & $437,330.60$ \\
Nusa Tenggara Barat & $1,291.47$ & $4,919.98$ & $6,211.45$ \\
Nusa Tenggara Timur & $235,503.57$ & $658,581.13$ & $894,084.70$ \\
Kalimantan Barat & $63,475.25$ & $144,121.15$ & $207,596.40$ \\
Kalimantan Tengah & $59,817.91$ & $199,588.36$ & $259,406.27$ \\
Kalimantan Selatan & $69,808.26$ & $273,436.59$ & $343,244.86$ \\
Kalimantan Timur & $117,053.19$ & $644,089.68$ & $761,142.86$ \\
Kalimantan Utara & $36,169.39$ & $118,580.05$ & $154,749.44$ \\
Sulawesi Utara & $46,396.49$ & $148,194.63$ & $194,591.12$ \\
Sulawesi Tengah & $41,405.01$ & $79,689.47$ & $121,094.48$ \\
Sulawesi Selatan & $114,334.91$ & $250,179.53$ & $364,514.44$ \\
Sulawesi Tenggara & $24,045.55$ & $61,661.27$ & $85,706.82$ \\
Gorontalo & $9,454.72$ & $30,380.26$ & $39,834.99$ \\
Sulawesi Barat & $13,999.44$ & $19,482.59$ & $33,482.03$ \\
Maluku & $20,539.08$ & $49,997.23$ & $70,536.32$ \\
Maluku Utara & $29,703.75$ & $64,347.35$ & $94,051.10$ \\
Papua Barat & $21,891.60$ & $73,563.81$ & $95,455.40$ \\
Papua & $157,804.49$ & $221,606.40$ & $379,410.89$ \\
Indonesia & $2,568,717.48$ & $16,197,814.90$ & $18,766,532.38$ \\
\hline & 5040.96 &
\end{tabular}

Source: Data processed 
Pratama \& Yuni $\mid$ Reducing Poverty through Optimization of Zakat on Agriculture and Profession

Compared to the GDP in Agriculture Sector, the potential zakat on agriculture is only about 0.1 percent of GDP. Although it is one-third of the total zakat collected by BAZNAS in 2017, the value is low yet. It probably caused by the limitation of this research only focused on self-employed workers whereas the big potential profit of the agriculture sector is in the employer-assisted by permanent/paid workers. This study omitting it because of the average wages in the kind of employment status is not available. The detail of the potential agricultural zakat is explained in the figure below.

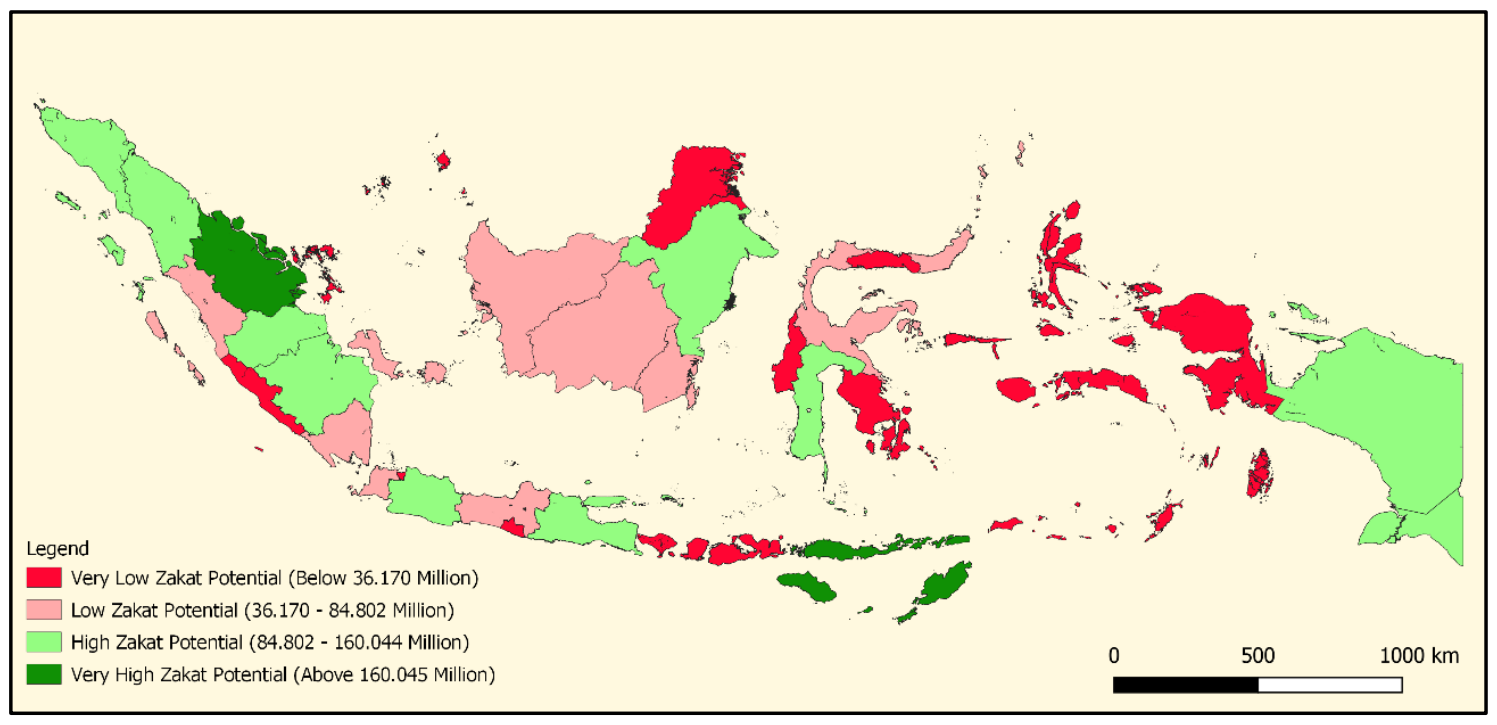

Figure 2. The Zakat Potential on Agriculture by Provinces in Indonesia Source: Data processed

Figure 2 shows the map of agricultural zakat potential in Indonesia. If we look thoroughly to five provinces that count on agriculture as a leading sector, these are Bengkulu, Sulawesi Tengah, Lampung, Gorontalo, and Sulawesi Barat, we will discover that the zakat potential on agriculture is categorized in red color in all those five provinces. It means that they are low and very low. Based on data from BPS-Statistics of Indonesia, the agriculture sector of all those provinces contributes more than 30 percent of GRDP. The values in 2016 consecutively are 30.66 percent, 31.26 percent, 31.86 percent, 37.09 percent, and 42.07 percent. It proved that the agriculture sector in those provinces is quite potential. This verdict is unexpected because the five provinces that have the most contribution to GRDP experience low zakat potential. Consequently, the zakat potential in these five provinces needs to be dug up further by conducting another research that is not only limited to the self-employed worker.

Several factors affect the low and very low agricultural zakat potential. Two of them are the total of muzakki in the regency and the welfare of the farmers. From the data collected, Sulawesi Barat and Gorontalo experienced 
Pratama \& Yuni | Reducing Poverty through Optimization of Zakat on Agriculture and Profession

a low number of total muzzaki. If it is compared to their Muslim population, the proportions are consecutively 6.82 percent and 6.75 percent, the second and the third-lowest of all provinces. The other provinces, Lampung, Bengkulu, and Sulawesi Tengah only have a 2-3 percent gap. The values are 8.56 percent, 8.90 percent, and 9.3 percent. Not only that but also the number of poor also worked in the agriculture sector is quite high. Bengkulu, Sulawesi Barat, and Sulawesi Tengah placed them in the 4th, 5th, and 6th rank of the muzakki that work in the agricultural sector. 40 percent in Bengkulu, 38.33 in Sulawesi Barat, and 36.57 percent in Sulawesi Tengah of the poor work in the farming sector (Sub-directorate of Social Vulnerability Statistics, 2019a). These mean that the farmers in those provinces mostly remain less prosperous so that they who are feasible to be muzakki are only a few.

Figure 2 also reveals another unique verdict. Papua that supposed to be low for zakat potential surprisingly has high of it, though 68.24 percent of the muzakki work in the agricultural sector. Notwithstanding, the proportion of muzakki and Muslims is about 16 percent or in the 10th grade compared to the other provinces. This circumstance is similar to the condition of NTT which gains the second-highest zakat potential on agriculture although 51.92 percent of the poor work in the agricultural sector. From these facts, a hypothesis developed that Muslims in NTT and Papua specifically who work in agriculture tend to have more assets than Muslims in other provinces leading to a presumption that the majority of poor people who worked in agriculture may be Non-Muslims. Albeit, those assumptions need to be studied thoroughly and carefully and cannot be concluded with less evidence.

Back to the analysis of zakat potential on profession, Figure 2 describes the result of the measurement by the province in quite comprehensive design. DKI Jakarta and Jawa Barat become the highest potential of zakat. It is relevant because DKI Jakarta is the province with the highest provincial minimum wages (UMP) in 2019 which reach to 3,940,973 rupiahs (Debora, 2018). This amount is high enough even nearly equal with the nisab of zakat. Moreover, the percentage of employees in Jakarta compared to other employment statuses is 65 percent, the second-highest in Indonesia. So, the zakat on profession undoubtedly is a real potential in Jakarta. Meanwhile, Jawa Barat even the UMP is not as excellent as Jakarta, the total number of laborers is the largest of all provinces, around 10.1 million people. Even the second largest province is only 7.4 million. This number of laborers is potential if the zakat is collected from their incomes. 
Pratama \& Yuni $\mid$ Reducing Poverty through Optimization of Zakat on Agriculture and Profession

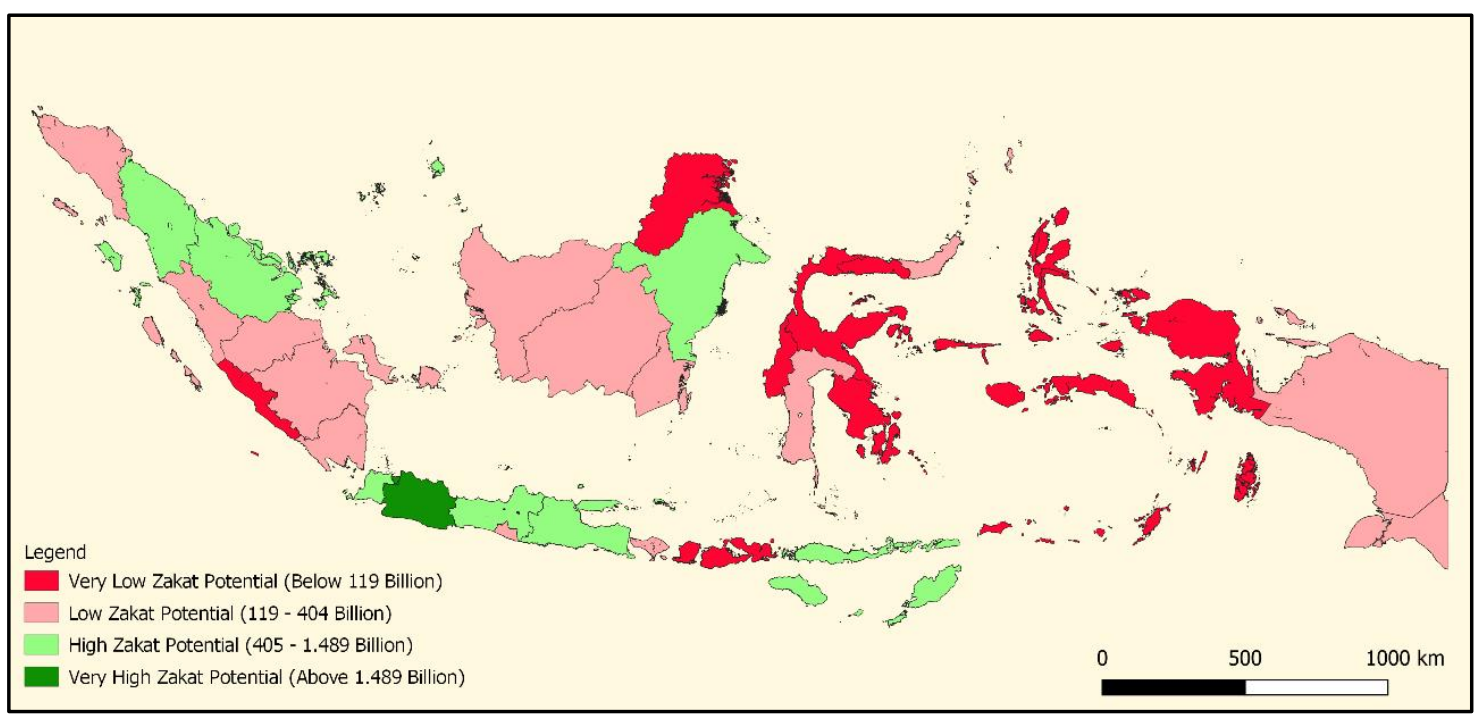

Figure 3. The Zakat Potential on Profession by Provinces in Indonesia Source: Data processed

In general, Jawa is the most potential island for profession zakat. Whereas Maluku and Papua along with Sulawesi are lack potential thus those provinces are mapped as red. If the potential agriculture zakat's map appears to be well-distributed, the different views appeared in the profession zakat mapping. Western Indonesia manages to have more potential zakat than Eastern Indonesia does. It perhaps caused by the sum of laborers. The 10 provinces that have the highest workers as employees are in Western Indonesia, meanwhile, the fifth-highest are in Jawa. Whilst in Eastern Indonesia, 9 of 10 provinces with a small number of Muslims are populated. Therefore, it is presumable the western overtakes the eastern from the aspect of zakat potential. Although there is a concentration of laborers in Jawa, not all provinces are classified as green or potential. Yogyakarta is lacking the potential of profession zakat. Yogyakarta's low UMP that is only $1,570,922$ rupiahs, the lowest of all provinces in Indonesia, becomes the main reason why profession zakat is lacking potential. Besides, Sumatera Selatan and Sulawesi Selatan require to be underlined. The total employees for both of them are numerous, continuously 2.8 million, and 1.4 million population. They are the sixth and seventh of all provinces. Moreover, the UMP in both provinces reaches 2.8 million rupiahs. The potential of profession zakat in these two provinces requires to be analyzed further.

There are at least seven provinces in Indonesia experienced a very lack potential of zakat both on agriculture and the profession. Those are Bengkulu, Kalimantan Utara, Sulawesi Barat, Nusa Tenggara Barat, Gorontalo, Maluku, and Maluku Utara. Among all the provinces, three of them, Bengkulu, Gorontalo, and Nusa Tenggara Barat are the provinces with majority Muslims. Yet, the zakat collection remains low. The major reason is 
Pratama \& Yuni | Reducing Poverty through Optimization of Zakat on Agriculture and Profession

the number of muzakki. In Gorontalo, there is only 69,350 people or 6.85 percent of total Muslims whose obligatory to pay zakat. This is the thirdlowest of all provinces after Sulawesi Barat and NTB. Severely, there are only 21,052 individuals or only 0.48 percent of Muslims in NTB who are identified as muzakki. These facts reveal why Gorontalo and Nusa Tenggara Barat are lacking the potential for this kind of zakat.

The case for Bengkulu is a bit different. There are about 148,704 muzakki in Bengkulu. This number is not a little, even Bali has 105.857 muzakki. The matter that occurred in Bengkulu is more likely because of the economic and social conditions of the province. There are several reasons to explain this inter alia; the poor people mostly work in agriculture (4th highest in Indonesia), the least number of muzakki $(148,704$ people, 11th lowest in Indonesia), the small amount of UMP $(2,040,000$ rupiahs, 7 th cheapest in Indonesia), and the low total of the employee both in number and proportion (7th lowest of employee proportion, 6th fewest number of the employee). It appears that Bengkulu has no zakat potential both on profession and agriculture. Further studies about the potential of zakat in Bengkulu will be extremely appealing.

By mapping the zakat potential on profession and agriculture as it is previously shown, we able to obtain the picture of the location where zakat on profession has potency and whereabouts zakat on agriculture is effective. Meanwhile, zakat on agriculture is quite effective to be obtained in almost provinces in Sumatera while zakat on profession is efficacious in Jawa. The potency of zakat on agriculture can be more dug up in Bengkulu, Sulawesi Tengah, Lampung, Gorontalo, and Sulawesi Barat. On the contrary, if we aspire to aim more zakat on profession, Sumatera Selatan and Sulawesi Selatan perchance to be great alternatives. This due to their high UMP (the 7th and the 8th highest of all provinces) and their high capacity of employees (also the 7th and the 8th most of all provinces) although the potential of profession zakat has remained below. At least, all the information has given some fundamental to build good and proper planning and organizing on zakat management development.

\subsubsection{How Zakat Contributes to Reduce Poverty}

The welfare of Indonesian society has a slowdown in the last five years. It is proven by the reduction of the poverty rate that is only 1.55 percent from September 2014 to March 2019. It indicated that in six months, poverty reduction is approximately only 0.172 . Surprisingly, the alleviation in the urban area appeared to be faster than in the rural ones. From September 2014 to March 2019, the percentage of poor people in urban diminished around 1.47 percent whereas, in rural, the poverty rate decreased only 
Pratama \& Yuni $\mid$ Reducing Poverty through Optimization of Zakat on Agriculture and Profession

about 0.91 percent throughout that time. This finding arises with a new analysis of the village funding use. Since the launching in 2015, all the data encourage to a thesis that the village funding did not give any significant impact to the poverty in an urban area because the decrease rate of poverty in a populated area is faster than in village ones though there is nonadditional funding in a rural area in the last five years.

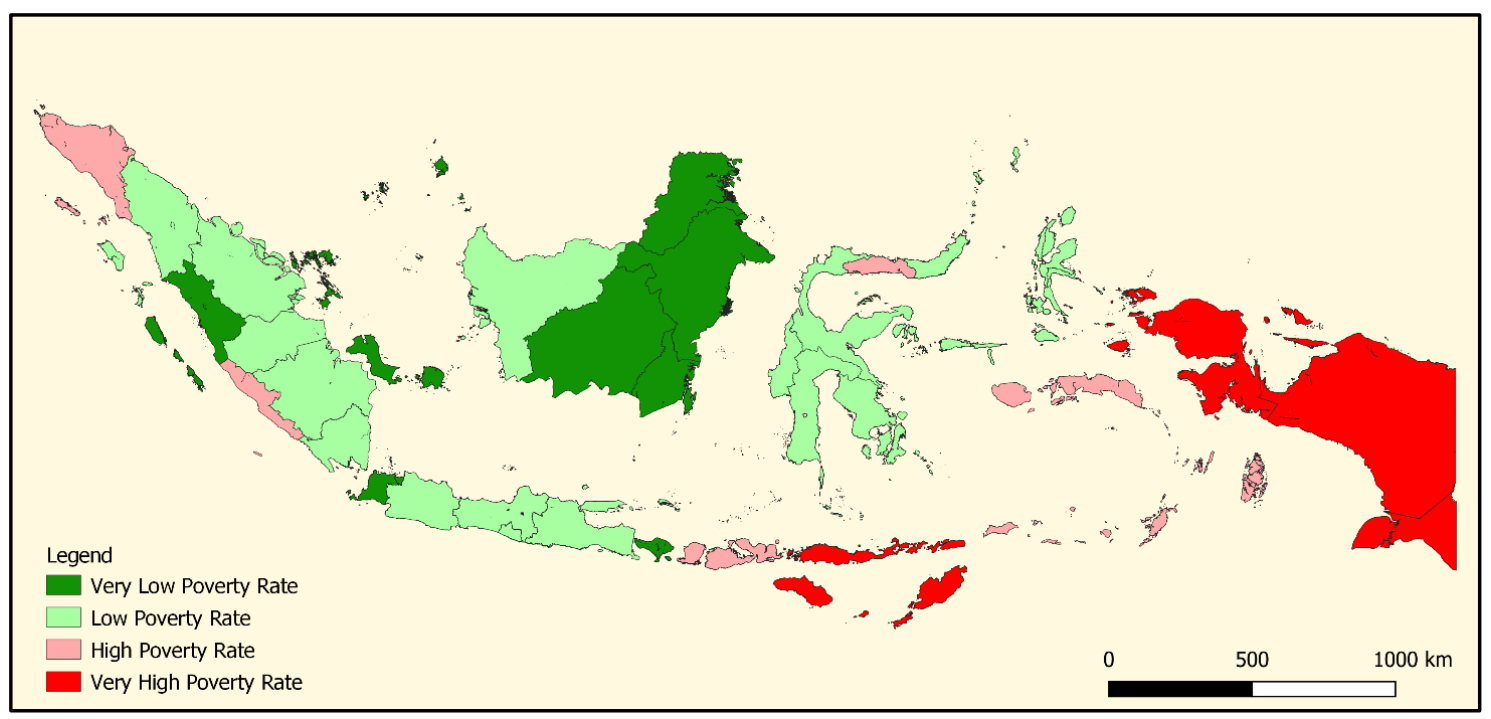

Figure 4. The Poverty Rate in 2019 by Provinces

Source: BPS-Statistics of Indonesia (2020), processed

Figure 4 describes the poverty rate among all provinces in Indonesia. It appears that the poverty rate is not over divergent because only a few provinces in Indonesia underwent a high poverty rate. It indicates that the equality of development that becomes the priority of development lately is starting to reveal some results. Kalimantan Island dominates the provinces with a very low poverty rate by presenting nearly all the provinces in dark green color except Kalimantan Barat. The poverty level in Kalimantan is successfully surpassing provinces in Jawa that are represented as the center of development for all this time. On the opposite, eastern Indonesia still become the center of poverty although it is not as bad as in the past whereas all provinces are vulnerable to poverty. NTT and Papua are still provinces with a very high poverty rate.

One point to note from the class distribution of the map is that classification in this poverty rate not applying Jenks Natural Breaks as applied previously but the fixed figure ones. At first, we make a scale from zero to the highest poverty rate figure and then divide the highest figure with four to form an interval. Hence, we have got the range of the first class that is $0-6.63$, the second class is $6.64-13.27$, the third class is $13.28-19.90$, and the last class is $19.91-26.55$. The following new poverty rate of all provinces will also be 
Pratama \& Yuni $\mid$ Reducing Poverty through Optimization of Zakat on Agriculture and Profession

classified using the interval. It is determined to be implemented to ease the interpretation and the analysis of how much the zakat potential role in Indonesia poverty reduction. The Jenks Natural Breaks method's using will create a new benchmark of each class so that it will be hard to identify provinces that underwent a great reduction of poverty rate effected by zakat potential.

Zakat has contributed to reducing poverty by fulfilling the amount of money that transferred to the poor so that they can be upward to the poverty line. The requiring transfer can be acquired by analyzing the poverty gap index. In Indonesia, the poverty gap index in March 2019 is 1.55 so the total transfer needed is 177.19 trillion rupiahs. The total zakat potential produced in this research is 14.41 trillion. If these funds are well-distributed on target later those will be able to cover 2 million people. Consequently, the poverty rate after the zakat distribution becomes 8.47 percent, only 0.75 percent down. It is only from the zakat of agriculture and profession. If we referred to specific research conducted by Firdaus et al. (2012) who counted the zakat potential from the household, manufacturing, and savings, the total of zakat reach 217 trillion. If that funding can be obtained and distributed in a proper target, later the poverty in Indonesia will disappear.

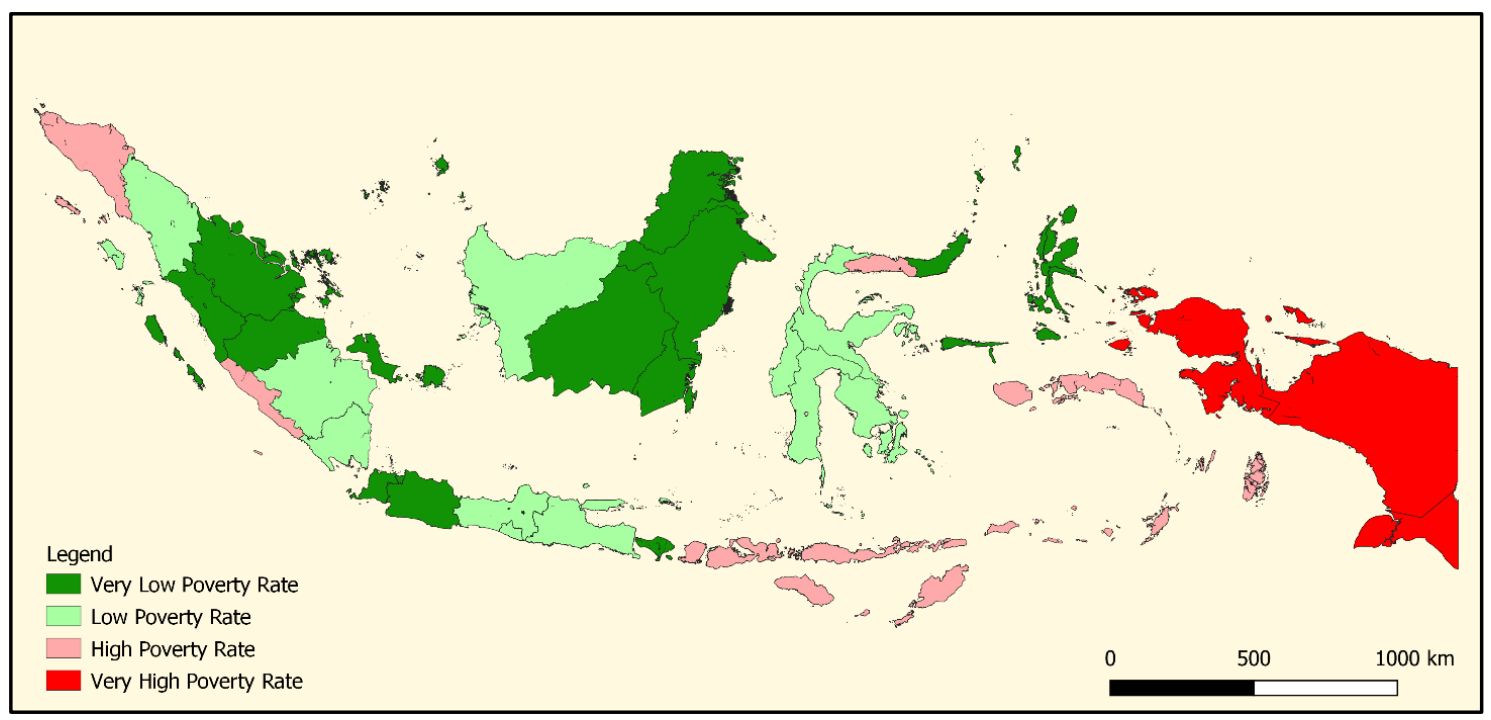

Figure 5. The Poverty Rate after the Distribution of Zakat Potential by Provinces Source: BPS-Statistics of Indonesia (2020), processed

Figure 5 is portraying the poverty rate obtained after the distribution of the amount of potential zakat to the poor following the perfect distribution presumption. At a glance, the map's look tends to be green. In western Indonesia, at least three provinces are successful to upgrade to a level higher among another Riau, Jambi, and Jawa Barat. Their amount of zakat potential can be strong factors affected because Jawa Barat is potential for zakat on 
Pratama \& Yuni | Reducing Poverty through Optimization of Zakat on Agriculture and Profession

profession and Riau is potential for zakat on agriculture. Another thing noticed is the province in crimson color is the one that left. Nusa Tenggara Timur has been able to increase one level into a province having high poverty after the zakat distribution. It means that the zakat instrument can be quite effective to eliminate poverty in NTT. However, in eastern Indonesia, Maluku Utara and Sulawesi Utara are provinces that can increase one level up too. Previously, Maluku Utara and Sulawesi Utara are categorized as provinces with a low poverty rate. After the zakat distribution, they now classified as very low poverty rates. Hence, zakat can be an effective instrument to fight poverty even in the province with Non-Muslim as the majority.

One thing underlined from the method of zakat in reducing poverty is the distribution of zakat assumed to be perfect. It means that all the poor are supposed to accept the funding evenly. It is extremely difficult to manifest. Nonetheless, there are several reasons which explain why zakat is resembling the assumption of perfect distribution as it is required by the poverty gap index analysis. Firstly, zakat has specific beneficiaries where the first two are the poor and the needy so that zakat funding is not supposed to be used for other programs except for the poor only. Secondly, the method applied to determine the recipient of zakat is by using the information from the nearest neighborhood and also the data published officially by the government. The research conducted by Ariyani, (2016) provided evidence that well-managed zakat produces an effective approach to reducing poverty. One of the good managements exemplified in the research is combining bottom-up and topdown methods. Lastly, zakat is a part of the prayer for Muslims so that everyone whose obligatory to pay demanding their funds for being welldistributed to the exact beneficiary. It will indirectly create a public-control of the funding so that the funds will be invulnerable to misuse. Therefore, optimizing the potential of zakat and developing the zakat institution will be very promising to actualize the zero-poverty goal. This impact may be even greater than the utilization of village funding in the case of poverty alleviation.

\subsubsection{The Regression Result}

We were working on the linear regression model on the impact of the zakat potential of agriculture and the profession on the poverty gap. It did not run well actually but we managed to find the solution. Firstly, our model was not a normal distribution, so we need to solve this by doing the logarithmic natural transformation. The disturbance of the assumption has not ended up yet. The transformation model had autocorrelation so the regression's result will be spurious (Wooldridge, 2009). So, we run the generalized least square regression and here is the result.

International Journal of Islamic Economics and Finance (IJIEF), 3(2), SI, 145-174|163 
Pratama \& Yuni | Reducing Poverty through Optimization of Zakat on Agriculture and Profession

$$
\widehat{P_{m}}=0.49+0.26 Z_{t}^{*}-0.24 Z_{p}^{*}
$$

This equation finally has fulfilled all the assumptions of multiple linear regression. The multicollinearity did not occur after considering the value of VIF (Variance Inflation Factor). Both independent variables have VIF's value of 2.601. The value is smaller than 5 so it concluded that there is no multicollinearity. Hence, the White test was conducted to detect heteroscedasticity. The value of $n R^{2}$ is 2.31 which is greater than the Probability of Chi-square. Thus, there is not enough evidence to reject the constant variance. Normality is tested using the Kolmogorov Smirnov test. The $p$-value resulted from the test is 0.2 , greater than 0.05 of a significant level. It means that the null hypothesis cannot be rejected so we are sure that the distribution of data is normal. Ultimately, the detection of autocorrelation is generated by calculating the Durbin Watson statistic (DW statistic)'s value. The value is 1.856 that located between du (1.58) and 4-du (2.42). If the DW statistic is within the interval, then there is no autocorrelation. Therefore, the estimation in the model is statistically valid and reliable so it can be well interpreted in explaining the impact of zakat on poverty.

The Adjusted $R^{2}$ is the value that explains the effect of the independent variables (zakat on agriculture and profession) toward the dependent variable (poverty). The value is 0.1145 or 11.45 percent meaning that the poverty gap is affected by all the independent variables as much as 11.45 percent, and the rest are impacted by other variables out of the model. There are many factors that cause the poverty gap such as inflation, job security, economic growth, and even other kinds of zakat. It seems reasonable. Notwithstanding, the small amount of the impact can be caused by many things such as so many zakat potentials that have not covered yet in this research.

The equation shows that zakat potential on profession has a significant impact on the poverty gap index. It means that the collection of zakat potential on the profession enables to reduce the average income gap between the poor and also the poverty line. Every increment in zakat potential on the profession as much as 10 percent will affect the gap between the average income of the poor and the poverty line reduced by 2.4 percent. Similarly, the potential zakat on agriculture which is also significant at a 5 percent level has the positive direction of the relationship. It signifies that for each increment of 10 percent potential zakat on agriculture will affect the increase of the income gap between the poor and the poverty line at 2.6 percent. This result contradicts the preliminary theory. 
Pratama \& Yuni | Reducing Poverty through Optimization of Zakat on Agriculture and Profession

Some reasons can explain why agricultural zakat has the same direction as the poverty gap. The main reason perhaps caused by the determination of agricultural zakat which is approached by average wages. Agricultural zakat does not give any impact on people's welfare. Instead, poor people who work in the agricultural sector tends to continue. So, when the incomes of the farmers are allocated for zakat, then the average incomes of total workers in the agricultural sector is reduced. The increase of the poor who works in the agriculture sector is supported by the data from BPS-Statistics Indonesia that the poor farmers in 2018 are about 49 percent then rise to 49.41 percent in 2019 (Sub-directorate of Social Vulnerability Statistics, 2018, 2019b). There is no meaningful impact of agricultural zakat on poverty, the average incomes that are reduced, and the poor farmers that increase conceive the evidence that agricultural zakat causes the poverty gap widened. The research from Abdulhakim \& Alamsyah (2011) and Khumairoh (2018) concluded that agricultural zakat did not significantly benefit the economics and society. Abdulhakim \& Alamsyah (2011) use the amount of money as an approach and found that people tend to pay Zakat Al-Fitr or other kinds of zakat except agriculture's whereas Khumairoh (2018) only provide rice as zakat payment.

Another reason is the approach used to measure potential zakat on agriculture which is turned to money. The amount of zakat on agriculture, based on the theory, is not paid with money but agricultural products. If farmers are harvesting their dates, they have to pay zakat by the time their products reach the nisab. So, the form of zakat is 5 percent of harvested dates, not the money gained from the result. Even in Qur'an Surah AlBaqarah Verse 2, Allah commands to pay zakat with the best quality of products (Sabiq, 2013). So, when the potential of agriculture zakat is approached by money, the effect will be on the income of farmers so it will increase the income gap of the poor and the poverty as explained before. Although some scholars perhaps pay zakat with money, it is proven that the enthusiasm of people is very low as it is studied by Abdulhakim \& Alamsyah (2011). However, perceiving the exact approach to measure agriculture zakat potential mainly at the national level is quite complex. It needs a huge amount of funds and resources. It is the main reason why this research is using this approach. At least, the general views about the location where agricultural zakat has potency can be defined. Nonetheless, future research is not recommended by using this approach because it is proven that it is not effective. 
Pratama \& Yuni | Reducing Poverty through Optimization of Zakat on Agriculture and Profession

\subsection{Analysis}

This study has attested that zakat on profession has a great impact on poverty. Its potency is capable to reduce the poverty rate in some provinces such as Kepulauan Riau and Bali below 2 percent and even below 0.5 percent in Jakarta. The regression result also shows that it has a significant impact on the poverty gap reduction that it can reduce 2.4 percent of the poverty gap if the zakat potential on the profession increases by 10 percent. Zakat on profession is also a kind of zakat that is almost capable to be controlled by the government because most people whose obligatory to pay zakat are the civil servants. Accordingly, we only need to complete the management of this kind of zakat from upstream to downstream so that the impact of zakat will be very effective to reduce poverty.

The best example of zakat management is looking at the way people had their success in managing zakat in the past. In the era of Caliph Umar Bin Khattab and Umar Bin Abdul Aziz, zakat is very effective so that it can eradicate poverty. Many studies said that in the era, there was zero absolute poverty (Arif, 2017; Nazri et al. 2012). At least two main strategies behind the success of Umar bin Abdul Aziz; 1) the act of justice from The Caliph creates trust between the people and the Caliph so it was not hard to collect zakat from the wealth, and 2) local distribution of funds, so the collected zakat must first be distributed to the area of the poor where it was taken. The zakat would go to the nation only if the poor of the region had been satisfied and then it will be directed to poor people in another region which is not fulfilled (Tahir, 2015). Meanwhile, in the time of Caliph Umar bin Khattab, his key to success in zakat management is the policy to decentralize zakat distribution (S. Aisyah \& Ismail, 2019). The one to be bold from those two eras is that zakat was distributed by local distribution system so the zakat beneficiaries will be prioritized to get the aid from the location where zakat is collected. If there is a surplus, it will be allocated to the nearest region.

According to the experience in the past, the solution to zakat management is the local distribution which is very hard to implement at this time. It is shown by the data about aid recipients from the government which always has a big chance to be deceived. Despite, the implementation of this local distribution might be able to do by utilizing the function of the mosque. The mosque is more entrusted than any institution. It can be shown that in Eid Al-Fitr when people have to pay zakat, most Muslims come to the mosque to pay their zakat rather than to the zakat institution. Moreover, the research from Hasim (2017) about the management of the mosque in Yogyakarta concluded that people can obtain the economic benefit from the mosque. Even in Yogyakarta, the management of zakat done by the Jogokaryan Mosque experienced the best achievement with percentages of about 85.71

International Journal of Islamic Economics and Finance (IJIEF), 3(2), SI, 145-174|166 
Pratama \& Yuni | Reducing Poverty through Optimization of Zakat on Agriculture and Profession

percent. Besides, zakat management in the mosque can identify the real poor in the region. If they are equipped by the preliminary data from the government, the combination of bottom-up and top-down data as suggested by Ariyani (2016) can be implemented. The mosque officer is ordinarily more honest because they pray continuously and serve the people well just expecting God's blessing. They are also and more trusted by people. Thus, the possibility to mistreat the zakat funds is smaller.

Utilizing the mosque does not mean that BAZNAS has nothing to do with that. Conversely, BAZNAS has a crucial role in the success of this concept. BAZNAS must assess the regency which mosque that has been ready. The collection of zakat on profession should be through BAZNAS because it is more possible if it is related to the civil servant. But, BAZNAS also must announce that their funds will be distributed through the mosque around them. BAZNAS will determine the amount of money needed in each region. This new method may be able to improve the collection of zakat funding and the impact on the welfare of people. In spite, the cooperation from all people including religious leaders in every region is fully needed. Considering the findings in this research, this new management method may be eligible to be implemented in Jakarta and Jawa Barat first as the provinces with the most potential of zakat. It can then be evaluated. If it is success, it can be prevailed gradually in other provinces by considering the potential of zakat (as it is provided in this research) and the readiness of the local government.

\section{Conclusion and Recommendation}

\subsection{Conclusion}

The total potential zakat in Indonesia (the sum of agricultural and profession zakat potential) reach 16.1 trillion rupiahs with DKI Jakarta and Jawa Barat as the most provinces with the highest amount of zakat potential. Both the provinces also have the most potential of zakat on profession whereas the most potential of agricultural zakat is in NTT and Riau. Provinces such as Bengkulu, Sulawesi Tengah, Lampung, Gorontalo, and Sulawesi Barat have great potential for the agriculture sector according to the structure of GDP. However, the potential of agricultural zakat in those provinces is still low. Similarly, Sumatera Selatan and Sulawesi Selatan also are the provinces with high UMP and the big number of employees. But, the potential of profession zakat in both of them is quite small.

Zakat can contribute to reducing poverty by minimizing the poverty gap between the average income of the poor with the poverty line. In Indonesia, 
Pratama \& Yuni | Reducing Poverty through Optimization of Zakat on Agriculture and Profession

in the assumption of perfect distribution, this zakat potential can reduce the poverty rate as much as 0.75 percent. Even Jakarta has the new poverty rate after being simulated by distributing zakat to 0.22 percent (almost zero). Riau, Jambi, and Jawa Barat are also successful to upgrade their poverty rate to a very low poverty rate. Surprisingly, NTT can leave the very high poverty rate because of this zakat potential. In the view of statistic, the kind of zakat which has a significant impact in minimizing the gap between the poor and the poverty line is zakat on profession. Every increase of the potential zakat on profession about 10 percent will affect the reduction of the poverty gap by about 2.4 percent.

\subsection{Recommendation}

All those effects of zakat on poverty are under the perfect distribution assumption. Zakat is the instrument that is closer to the assumption. So, it is all depended on zakat management. In the era of Caliph Umar bin Khattab and Umar bin Abdul Aziz, the management of zakat count on local distribution. This is their key to success. Therefore, this study suggests imitating the management process in the times by utilizing the mosque as a spearhead in zakat distribution and BAZNAS as the key manager to manage the mosque and the zakat funding. The implementation of top-down and bottom-up data about the zakat recipient can be implemented by this system so that zakat will be distributed on target. Jogokaryan mosque in Yogyakarta can be a good role model in implementing this because it has proved as the mosque with good management of zakat in Indonesia. The regulator must try to implement this starting with Jakarta and Jawa Barat first as they are the provinces with the most potential zakat. If they are success, then it can be more developed gradually. The map of potential zakat provided in this research can be used as a reference to choose the provinces as the next target to be expanded.

As the regulator can start with zakat on profession because it is very possible as the government has the power, the zakat institutions can strengthen the potency of agricultural zakat and implement the local distributions zakat system. The provinces with can try to start maximizing the potential of agricultural zakat is NTT and Riau as they are the most potential zakat on agricultural product. The one to note is the collection of agricultural zakat must be based on agricultural products, not the money or income because it is not effective. It will be great if the zakat institution can apply this system to one village first and then expand it if it is success. 
Pratama \& Yuni | Reducing Poverty through Optimization of Zakat on Agriculture and Profession

Further studies are not recommended by using the approach of this research specifically in approaching the amount of agricultural zakat. In this research, it is proven that the bias in this method makes the zakat potential on agriculture widen the poverty gap from the poverty line. It is better if the future studies specifically on agricultural zakat can cover the real amount of zakat in the form of agricultural product as it is required by the Sharia, not by the approach of money or wages. Even on a smaller scale, the result of the study will be very useful to detect the real potential of agricultural zakat in this Agraris Country. Not only that, but this paper also encourages to conduct more researches about specific kinds of zakat whether it is regarding the collection, management or even distribution and also, it will be great if more researches similar to this are conducted in a regencies/municipalities level in provinces with great potential of zakat. The author suggests developing more research about agricultural zakat in Bengkulu, Sulawesi Tengah, Lampung, Gorontalo, and Sulawesi Barat and profession zakat in Sumatera Selatan and Sulawesi Selatan. 
Pratama \& Yuni | Reducing Poverty through Optimization of Zakat on Agriculture and Profession

\section{References}

Abdulhakim, M. T., \& Alamsyah, D. S. (2011). Model perhitungan zakat pertanian dan perhitungan ekonomi zakat di kecamatan Cileunyi kabupaten Bandung. Economic Policy, 2116, 0-33. doi:10.1227/01.NEU.0000349921.14519.2A

Ahsan, A., Wiyono, N. H., \& Hidayat, Z. (2009). Pemetaan mustahik, muzakki dan potensi pemberdayaan Indonesia. Retrieved from https://www.researchgate.net/publication/301197921

Aisyah, M. (2014). The role of zakah and binary economics in poverty reduction. Esensi: Business and Management Journal, 4(2), 178-197. Jakarta: Syarif Hidayatullah State Islamic University of Jakarta

Aisyah, S., \& Ismail, N. (2019). The distribution of zakat at the time of caliph Umar ibn Khattab. Al-Iktisab: Journal of Islamic Economic Law, 3(2). doi: 10.21111/al-iktisab.v3i2.3908

Arif, M. (2017). Zakat as a mode of poverty alleviation. International Journal of Economics \& Management Sciences, 06(06), 57-65. doi: 10.4172/2162-6359.1000473

Ariyani, N. (2016). Zakat as a sustainable and effective strategy for poverty alleviation: from the perspective of a multi-dimensional analysis. International Journal of Zakat, 1(1), 89-107. Retrieved from https://ijazbaznas.com/index.php/journal/article/view/9/7

Asfarina, M., Ascarya, A., \& Beik, I. S. (2019). Classical and contemporary fiqh approaches to re-estimating the zakat potential in Indonesia. Journal of Islamic Monetary Economics and Finance, 5(2). doi: 10.21098/jimf.v5i2.1068

Asra, A., Utomo, A. P., Asikin, M., \& Pusponegoro, N. H. (2017). Analisis multivariabel: Sebuah p77777engantar. Jakarta: Inmedia.

BPS-Statistics of Indonesia. (2020). Statistical Yearbook of Indonesia 2020. Jakarta: BPS-Statistics Indonesia.

Center of Strategic Studies -Amil Zakat National Agency. (2019). Indonesia zakat outlook 2019. Retrieved from https://www.puskasbaznas.com/publications/outlook/indonesia-zakatoutlook-2019/899-indonesia-zakat-outlook-2019

Debora, Y. (2018). Daftar UMP 2019: Jakarta tertinggi, Yogyakarta terendah (List of UMP 2019: Jakarta the highest, Yogyakarta the lowest). Retrieved June 2, 2020 from https://tirto.id/daftar-ump-2019-jakartatertinggi-yogyakarta-terendah-c88h

Division of Integrated Processing and Statistical Disemination. (2012). The characteristic of people in East Kalimantan Province: The result of Population Census 2010. Samarinda: BPS-Statistics of Kalimantan Timur. 
Pratama \& Yuni | Reducing Poverty through Optimization of Zakat on Agriculture and Profession

Firdaus, M., Beik, I. S., Irawan, T., \& Juanda, B. (2012). Economic estimation and determinations of Zakat potential in Indonesia. IRTI Working Paper Series: Vol. WP 1433-07 (Issue August). Jeddah: Islamic Research and Training Institute

Hair, J. F., Black, W. C., Babin, B. J., \& Anderson, R. E. (2010). Multivariate data analysis. New Jersey: Prentice Hall Inc.

Hasim. (2017). The implementation of baitul maal management in early islam as the alternative to increasing people's economy: Case study on the management of mosque in Yogyakarta. Paper presented at The International Conference of Arts, Language and Culture, University of Sebelas Maret.

Haughton, J., \& Khandker, S. R. (2009). Handbook on Poverty and Inequality. Washington DC: The World Bank.

Huda, N., Nasution, M. E., Idris, H. R., \& Wiliasih, R. (2008). Ekonomi Makro Islam - Pendekatan Teoritis. Jakarta: Kencana Prenada Media Group.

Ismail, A. G. (2013). Theoretical Model for Zakat -Based Islamic Microfinance Institutions in Reducing Poverty. International Research Journal of Finance and Economics, 103, 136-150. Retrieved from http://www.internationalresearchjournaloffinanceandeconomics.com

Jiang, B. (2012). Head/tail breaks: A new classification scheme for data with a heavy-tailed distribution. Professional Geographer, 65(3), 482-494. doi: 10.1080/00330124.2012.700499

Kausar, A., Alauddin, M., \& Rokibul Kabir, M. (2016). A masjid based zakat management model in alleviating poverty: bangladesh perspective. International Journal of Ethics in Social Sciences, 4(2), 2308-5096. Retrieved from http://www.crimbbd.org/wpcontent/uploads/2017/06/4.2.6.pdf

Khumairoh, A. (2018). Implementasi zakat hasil pertanian dalam peningkatan kesejahteraan ekonomi masyarakat di desa Balekencono kecamatan Batanghari (Bachelor's Thesis). Metro: Institut Agama Islam Negeri Metro.

Ministry of Religion. (2011). Petunjuk pelaksanaan pengumpulan zakat. Jakarta: Ministry of Religion.

Mujiatun, S. (2018). The Constraints of Management of Zakat and Its Potentials in Poverty Reduction (Case Study Medan City). Advances in Social Sciences Research Journal, 5(6), 104-109. doi: 10.14738/assrj.56.4673

Nazri, F. A. A., Rahman, R. A., \& Omar, N. (2012). Zakat and poverty alleviation : roles of zakat institutions in Malaysia. International Journal of Arts and Commerce, 1(7), 61-72. Retrieved from https://www.researchgate.net/publication/255768084 
Pratama \& Yuni | Reducing Poverty through Optimization of Zakat on Agriculture and Profession

Novignon, J., Nonvignon, J., Mussa, R., \& Chiwaula, L. S. (2012). Health and vulnerability to poverty in Ghana: Evidence from the Ghana living standards survey round 5. Health Economics Review, 2(1), 1-9. doi: 10.1186/2191-1991-2-11

Peerzade, S. A. (1997). The definition and measurement of poverty: An integrated islamic approach. The Pakistan Development Review, 36(1), 87-97. Retrieved from https://www.jstor.org/stable/41260020

Rahman, M. F. A., Rahman, A. A., Thaidi, H. A. A., Abdullah, L. H., Anwar, S. M., Bakar, M. F. A., \& Ahmad, U. S. (2014). The inconsistency of assessing agricultural zakat. Global Journal Al-Thaqafah, 4(1), 17-31. doi: 10.7187/GJAT512014.04.01

Rarasati, I., \& Dewanti, D. S. (2018). Poverty alleviation through zakat and income distribution on agriculture of local commodity, honey pinneapple, in Pemalang regency. Paper presented at The 2nd International Conference on Technology, Education, and Social Science 2018.

Rosele, M. I., Ramli, M. A., Ismail, M. Z., \& Ariffin, M. F. M. (2014). Zakah on agriculture reformation: An analysis in Malaysia. Sains Humanika, 3(1), 47-53. Johor Bahru: Penerbit UTM Press

Sabiq, S. (2013). Fiqh Sunnah Jilid 2. Jakarta: Tinta Abadi Gemilang.

Shirazi, N. S., Amin, M. F. Bin, \& Anwar, T. (2009). Poverty elimination through potential zakat collection in the OIC-Member countries: revisited. The Pakistan Development Review, 48(4), 739-754. Retrieved from http://www.jstor.org/stable/41261344

Smith, M. J. de, Goodchild, M. F., Longley, P. A., \& and Associates. (2018). Geospatial analysis. Retrieved from www.spatialanalysisonline.com

Sub-directorate of Social Vulnerability Statistics. (2018). Penghitungan dan analisis kemiskinan makro Indonesia 2018. Jakarta: BPS-Statistics of Indonesia.

Sub-directorate of Social Vulnerability Statistics. (2019a). Data dan informasi kemiskinan Kabupaten/Kota 2019. Jakarta: BPS-Statistics Indonesia.

Sub-directorate of Social Vulnerability Statistics. (2019b). Penghitungan dan analisis kemiskinan makro Indonesia 2019. Jakarta: BPS-Statistics of Indonesia

Syafa, A. K., Ana, L., Ekaningsih, F., Inayah, N., \& Jauhariyah, N. A. (2020). The management of professional zakat in overcoming the poverty in Tegalsari district regency of Banyuwangi East Java Indonesia. Paper presented at the International Conference on Industrial Engineering and Operations Management.

Tahir, I. N. (2015). Socio-economic reforms in line with the Maqāsid AlSharīah: The case of Caliph 'Umar ibn 'Abd al-'Azīz. Al-Shajarah, 20(2), 
Pratama \& Yuni | Reducing Poverty through Optimization of Zakat on Agriculture and Profession

211-246.Kuala Lumpur: International Institute of Islamic Thought and Civilisation.

Widjaja, Y. P. A. (2018). Headline: Gaji PNS dipotong untuk zakat. Bagaimana mekanismenya?. Retrieved May 30, 2020 from https://www.liputan6.com/news/read/3269642/headline-gaji-pnsdipotong-untuk-zakat-bagaimana-mekanismenya

Wooldridge, J. M. (2009). Introductory Econometrics : A Modern Approach. Toronto: Nelson Education, Ltd. 
Pratama \& Yuni | Reducing Poverty through Optimization of Zakat on Agriculture and Profession

This page is intentionally left blank

International Journal of Islamic Economics and Finance (IJIEF), 3(2), SI, 145-174|174 